\title{
What Lies at the Intersection of Law and Psychiatric Nursing? Exploring the Process of Judiciarization in the Context of Mental Health.
}

\author{
Etienne Paradis-Gagné1, Jean-Daniel Jacob ${ }^{2} \&$ Pierre Pariseau-Legault $^{3}$ \\ ${ }^{1}$ Faculty of Nursing, Université de Montréal, ${ }^{2}$ School of Nursing, University of Ottawa, \\ ${ }^{3}$ Department of Nursing, Université du Québec en Outaouais
}

Cite As: Paradis-Gagne, E., Jacob, J.D. \& Pariseau-Legault, P. (2020). What lies at the Intersection of Psychiatric Nursing? Exploring the Process of Judiciarization in the Context of Mental Health.Witness: The Canadian Journal of Critical Nursing Discoruse, Vol 2(2), pp 3-19 https://doi.org/10.25071/2291-5796.72

\begin{abstract}
:
In this article, our aim is to provide a critical analysis of the phenomenon of judiciarization of people diagnosed as mentally ill and its impact on nursing practice. In order to explore the issues inherent to this phenomenon, we employed the methodology of discursive analysis greatly inspired by the work of French philosopher Michel Foucault. The results of this analysis push our reflection on the experiences and practices that take place at the psychiatric and judicial interface, engaging in a critique of underlying goals of public protection, social control, and pastoral power being incorporated to nursing practice. While acting in seemingly humanistic and therapeutic roles of care, nurses are simultaneously and inevitably fulfilling a mandate of social control which, to date, remains relatively under documented.
\end{abstract}

Key words: Foucault, pastoral power, mental health, psychiatric nursing, justice system involvement

\section{Introduction}

An increasing number of people diagnosed as mentally ill (PDMI) are finding themselves on a judicial trajectory in Canada (Mental Health Commission of Canada, 2012; Schneider, 2015). This phenomenon, known as judiciarization, is discussed in literature on criminalization of PDMIs and other historical works in the field of psychiatry, sociology and law. In these multidisciplinary writings, this increase in the interaction between psychiatric and judicial power is linked to the phenomenon of deinstitutionalization
(Dvoskin, Knoll, \& Silva, 2020), or what other authors rather define as transinstitutionalization (Prins, 2011; Schneider, 2015); that is, how individuals, supposedly de-institutionalized as a result of community care policies, ended up simply shifting and transitioning in different institutions, such as prisons, tribunals and psychiatric institutions, rather than their own homes. Thus, juridiciarization, as a relatively new concept, speaks to the increasing ways in which PDMIs come into contact with the judicial system, both civil and criminal (ParadisGagné \& Jacob, 2020; Centre for Addiction

Corresponding Author : Etienne Paradis-Gagné Facutly of Nursing, Université de Montréal.

Email: Etienne.paradis.gagne@umontreal.ca 


\section{The Canadian Journal of Critical Nursing Discourse}

\section{See it. Speak it. Write it. Change it.}

and Mental Health [CAMH], 2013; Gouvernement du Québec, 2018; PeterneljTaylor, 2008; Provencher, 2010), reinforcing both old and new forms of transinstitutionalization.

Of particular importance to this article, are the numerous issues often reported in relation to contemporary processes of judiciarization in the context of the psychiatric-judicial interface (Schneider, 2015). Among these issues is the fact that judiciarization disproportionately affects so-called "vulnerable populations" (Commission des droits de la personne et des droits de la jeunesse, 2009; Office of the Ombudsperson, 2019), as well as indigenous and racialized populations (CAMH, 2013; Watts \& Weinrath, 2017). Other reported issues in the literature include the increased stigma that affects PDMIs (Frappier, Vigneault, \& Paquet, 2009), and the detrimental effects judiciarization may have on families and relatives (Beaudoin \& Robert, 2012; ParadisGagné, Holmes, \& Perron, 2020). For example, having to involve the police in a crisis situation, initiating legal proceedings to obtain a request for a psychiatric assessment, or filing a complaint against a relative with severe mental disorder has serious consequences for the family (Paradis-Gagné et al., 2020). Recent studies also suggest that the judiciarization of vulnerable populations is no more effective than care offered on a voluntary basis (Kisely, Campbell \& O'Reilly, 2017) and can be counterproductive (Bello \& Sylvestre, 2017).

Nurses are particularly affected by the growing interaction between the psychiatric and judicial interface (Galon \& Wineman, 2010; Gournay, 2005; Kent-Wilkinson, 2010; Mason \& Mercer, 1996). As clinicians within this interface, they are present throughout the continuum of care, from street nursing, to emergency room admissions, inpatient treatment and community follow-up-all of which often include various forms of coercive intervention to which they participate. In Canada and Ontario more specifically, the vast majority of psychiatric admissions are now involuntary (Lebenbaum, Chiu, Vigod, \& Kurdyak, 2018). A report of the Ombudsperson of British Columbia also highlights the significant increase in involuntary psychiatric hospitalizations in recent years in the province (Office of the Ombudsperson, 2019), a situation also considered to be of concern in the province of Québec (Commissaire à la santé et au bien-être, 2012), and we would argue, across the nation as a whole. In forensic psychiatric nursing more specifically, ongoing difficulties are experienced by nurses who are regularly confronted with dual roles of care and control in the context of their work (Hörberg \& Dahlberg, 2015; Mason, 2002). The use of coercion as an intervention in the context of care, thus requires ongoing reflection on the part of nurses so as to ensure ethical practice.

It should be noted that coercion is a multifaceted concept (Pariseau-Legault, Vallée-Ouimet, Goulet, \& Jacob, 2019). It can be defined as either formal, or "hard" (Andersson, Fathollahi, \& Gustin, 2020), as well as informal, or "soft" (Valenti et al., 2015). For example, formal coercion is often associate to the use of seclusion, mechanical and chemical restraint, and involuntary hospitalization. Informal coercion may include such things as persuasion, threats to use harder forms of coercion, or undue pressure to comply with treatment (LeFrançois, 2014; Valenti et al., 2015). Although soft coercion may not be explicit or as tangible, it nevertheless enables its application to a wide range of people (e.g., people who are voluntarily hospitalized or cared for), and may be just as harmful, (re)traumatising, and oppressive for those who are subjected to it (Allison \& Flemming, 2019; Nyttingnes, Ruud, \& Rugkåsa, 2016). 
This article aims to provide a discourse analysis of the phenomenon of judiciarization of PDMIs and its impact on nursing practice. Inspired by the work of Michel Foucault, our analysis pays a particular attention to power relations inherent to the process at play in interacting with the judicial system - or what Foucault defined as the "psychiatric-judicial apparatus." According to Foucault (2003), this apparatus dates from long before the period of deinstitutionalization, as far back as the mid $19^{\text {th }}$ century. He contends that during this period, we witnessed a markedly intensified interaction between the psychiatric and judicial systems which, arguably, continues today and has become distinctly important in recent times (Mason and Mercer, 1996; Rogers \& Pilgrim, 2014). With this in mind, we aim to describe and critique how caring practices intersect with the judicial interface, and how they contribute to legitimize the judiciarization of PDMIs.

\section{Theoretical Framework}

Engaging in a Foucauldian discourse analysis requires, in part, the methodological approach to be framed in poststructural thought (Arribas-Ayllon \& Walkerdine, 2017; Cheek, 1999). Poststructuralism is a philosophical perspective that focuses on both the analysis of the exercise of power in society as well as a deconstruction of dominant discourses at play in relation to the phenomenon under study (Williams, 2005). Such theoretical framework enables researchers to pay particular attention the ethical and socio-political dimensions of the phenomenon under study (Williams, 2005).

Foucault is one of the central authors of poststructuralism, although he has always rejected the labelling and categorization of his ideas (Cheek, 1999). He has been particularly interested in care practices and social control in psychiatric settings, as well as the various forms of power (whether sovereign, disciplinary or pastoral) that are orchestrated in these environments (Elden, 2017). Foucault also studied the way certain social objects, situations and phenomena (e.g., madness and criminality) historically become problems to be investigated and treated (Foucault, 2009). This notion of "problematization of knowledge" (Cheek, 1999) is particularly useful for discourse analysis.

For Foucault, discourses (or discursive practices) come to legitimize certain knowledge (savoirs and connaissances), certain disciplines (law, medicine, psychiatry, nursing, etc.) and certain modes of thought as historically located hegemonic truths (Foucault, 1980). In other words, we can think of discourses as "regimes of truth" that creates a hierarchy between knowledges and that shape relations to self, others and the world (Foucault, 1980, 2010). Dominant discourses come to implement different mechanisms of power (be it sovereign, disciplinary, pastoral, etc.) in order to allow the subjection of people in society.

\section{Methodology}

In this article, we used the form of Foucauldian discourse analysis (FDA) proposed by Parker (2013) as our methodology. The approach proposed by Parker, which is grounded in Foucault's work and epistemology, is intended to guide the critique and questioning of dominant discourses in the health sciences and nursing: "This form of discourse analysis is always searching for points of conflict, something more visceral and subversive than mere methodological concern with "contradiction."' (Parker, 2013, p. 232). In this regard, it is important to note that the FDA is not a formalized approach with strict procedures and prescribed outcomes. As 
stated by Arribas-Ayllon and Walkerdine (2008): "there are no set rules or procedures for conducting Foucauldian-inspired analyses of discourse.” (p. 110)

Foucauldian discourse analysis refers to a critical re-reading of how knowledge takes shape, are deployed and become accepted as criteria of truth in contemporary societies (Parker, 2013). From Foucault's perspective, discourse analysis can thus be operationalized in different analytical stages:

1. To treat discourse not as a theme of reviving commentary, but as a monument to be described in its intrinsic configuration. 2. To investigate not the laws of construction of discourse, as it is done by those who use structural methods, but its conditions of existence. 3 . To relate the discourse not to a thought, mind or subject which engendered it, but to the practical field in which it is deployed. (Foucault, 1991, p. 61)

We proceeded with our Foucauldian discourse analysis (FDA) by first conducting a literature review following the iterative steps proposed by Paré and Kitisou (2017): formulating the aim of the research; searching the literature; screening for inclusion criteria; extracting data, and analysis of the data. For searching the literature, we used a combination of keywords (criminal justice, judiciarization, criminalization, procedural justice, mental health and mental disorder), using different databases: CINAHL, MEDLINE, PsycINFO and Érudit. A total of 1359 articles were sourced. We selected English and French language, international peer-reviewed articles $(n=22)$ that both presented the concepts in the abstract or title, and addressed it in the context of mental health nursing (or related health care context). We then proceeded to a grey literature search $(n=10$ documents) on the phenomenon under study (e.g., governmental reports from different Canadian provinces, documents produced by mental health advocacy groups) in order to contextualize the scientific literature to the Canadian context. In hindsight, the grey literature proved to be an important part of the process, as it allowed us to explore what Foucault has defined as marginal knowledges (Foucault, 1980); that is, aspects of the concepts that would have otherwise been left out of the review process. Lastly, we consulted the references in all publications to find other relevant sources $(n=15)$ for analysis.

Once all publications were sourced, the content of the papers were analyzed following steps inspired by Parker (2013) on FDA. The following are examples of questions that were asked of the literature consulted during the analytical process: How is the concept of judiciarization and those related to it mobilized in the text? What are the central ideas that stand out in this text? Are there reported power dynamic and social control issues? Is there the presence of dominant discourses, of "regime of truth" that are conveyed in the text? What are the conditions of existence of those discourses? What is not in the text, or what is left in the margin?

This process enabled us to tease out the ways in which we currently think about the phenomenon of judiciarization in the context of mental health, to then analyze these ways of thinking in light of inherent sociopolitical/power dynamics that constitute them.

\section{Findings}

The analysis of the literature reviewed led to the identification of three elements of the psychiatric-judicial apparatus. These elements are taken up in three main 
categories which are detailed below: 1) the construction of the judiciarized subject; 2) the instrumentalization of care as a strategy of control and 3) procedural justice as an extension of pastoral power.

\section{The Construction of the Judiciarized Subject}

Sociocultural geographer Robin Kearns (1993) writes: "[...] what occurs in a place (in terms of the relations between people and elements of their environment) has a profound importance to health" (p. 141). What we can draw from this quote is the inherent contextual nature of health experiences and the need to take into consideration how relations with our environment deeply affect us.

Shifting our thinking and focusing on the dialectical relationship between the elements that make up our environment (material, symbolic, human, etc.) and subjective experiences, enables us to look into how we come to understand ourselves and others (Poland, Lehoux, Holmes, \& Andrews, 2005). If we look at PDMIs, such a focus forces us to think about implicit and explicit relations of power that come to define how they are discursively constructed-taking into account those interrelated elements that surround them (material, social, symbolic, discursive, etc.) and come to define them. More specifically, we need to look at the ways in which PDMIs come into contact with the judicial system and become judiciarized subjects; that is, how they come to be known and constructed from a judicial lens. Such a focus supposes that we break from traditional frames of reference where PDMIs are subjected to the medical gaze or judicial structures, and that we take into consideration the emergence of a justice that is now described by its therapeutic nature (Foucault, 2003). How PDMI come to be placed on a judicial trajectory can take on various forms and be done in different ways. The following section speaks to these various forms and ways PDMIs come into contact with the judicial system and their effects. It also speaks to some of the conditions that enable judiciarization of PDMIs more generally; that is, the conditions that permit judiciarization of PDMIs to exist.

According to our review of the literature, judiciarization of PDMIs can occur in three distinct yet interrelated ways, positioning it on a continuum of experiences raging from criminalization, to everyday contacts with members of the justice system (e.g., police officers). In criminal matters, judiciarization may take place after a PDMI has committed an offence that may result in incarceration. In this regard, Schneider (2015) reports that persons diagnosed as mentally ill are overrepresented in the Canadian correctional system, although it is an environment where it can be difficult to provide appropriate mental health care (Dvoskin et al., 2020; Frappier et al., 2009; Protecteur du citoyen, 2011). Justice system involvement may also result in hospitalization in a forensic psychiatric setting for individuals found not criminally responsible on account of mental disorder (Schneider, 2015). In this instance, PDMIs are not criminalized per se, but are nevertheless integrated to the judicial system through hybrid medico-legal processes.

Lastly, judiciarization may not
necessarily lead to a form of imprisonment/hospitalization, but also refers to the multiple points of contact PDMIs may have with members of the justice systems in more or less formal ways. For instance, in the literature, interactions with police officers, as first responders to public disturbances or emergencies, are often reported (Kucirka \& Ramirez, 2019; Lamb \& Weinberger, 2013), and contribute to the construction of PDMIs as judiciarized subjects. In these instances, PDMIs' contact with social assistance 
services is done through a judicial interface (as opposed to medical), which includes documentation of their behaviours, record keeping of interactions, as well as associated methods of management. Although it may seem benign, these forms of interaction and associated documentation and management form a repertoire through which we come to see, understand, and intervene in the context of mental health; a specific set of relations that enable judiciarization of PDMIs.

In light of the context described above, and in order to avoid involving PDMIs in the criminal justice system, various diversion mechanisms have been put in place in Canada (Schneider, 2015). We argue, however, that despite its intentions of "diversion", such mechanisms work to expand current judiciarization mechanisms. Examples include specialized mental health courts (MHC), which allow for diversion from the criminal justice system to treatment in the community (Kopelovich, Yanos, Pratt, \& Koerner, 2013). These specialized courts were developed in the 1980s and are now established in different provinces (MacDonald, Bellot, Sylvestre, Michaud, \& Pelletier, 2014; Watts \& Weinrath, 2017). If these mechanisms are considered to meet therapeutic ends, they nonetheless create new spaces of surveillance and control outside the walls of traditional institutions such as prisons, hospitals, etc.

These are the societies of control, which are in the process of replacing the disciplinary societies. [...] For example, in the crisis of the hospital as environment of enclosure, neighborhood clinics, hospices, and day care could at first express new freedom, but they could participate as well in mechanisms of control that are equal to the harshest of confinements. (Deleuze, 1992, p. 4)
According to Deleuze (1992), contemporary societies of control (societies that coexist with the disciplinary ones) allow for increased surveillance/discipline while concurrently portraying or alluding to increased autonomy and freedom (O'Byrne \& Jacob, 2019). A good example of Deleuzian control mechanisms is the judiciarization of PDMIs achieved through civil mental health legislation, the workings of which may vary across provinces (Gray, Hastings, Love, \& O'Reilly, 2016). Civil court provisions can include community treatment orders (CTO), involuntary hospitalization and inpatient treatment authorization (Gray et al., 2016; O'Reilly, Keegan, Corring, Shrikhande, \& Natarajan, 2006). Although civil mental health legislations may be considered less adverse than the criminal justice system by enabling a certain level of freedom, autonomy and/or management in a health care facility, they still remain oriented towards social control and coercion through the management of conduct on a much larger scale; that is, through a growing number of institutions, community networks, etc. (Association des groupes d'intervention en défense des droits en santé mentale du Québec [AGIDD-SMQ], 2014; Gault, 2009; Nyttingnes et al., 2016). For nursing practice, this doesn't mean that traditional disciplinary interventions (working with the individual to change behaviours) are no longer in place. On the contrary, in societies of control, nurses do take part in these interventions while concurrently working on the conditions in which PDMIs live. This move away from disciplines allows for a type of control that permit/limit certain actions to take place, while fostering a sense of autonomy and concurrently maintaining a strategic gaze and possibilities for interventions. There is much to unpack here with respect to the role of psychiatric power in current societies and how this role is ultimately contributing to current processes of judiciarization. 
On the notion of freedom and autonomy, the work of French philosopher Michel Foucault reminds us that mental health legislations and judicial processes constitute neither a guarantee of freedom nor the protection of autonomy. On the contrary, judicial processes must be understood as mechanisms through which power operates, contributing to the construction of obedient/disciplined patients in increasingly diverse and subtle ways (Roberts, 2005). In the context of limited health services, the justice system represents an "institutional crystallization" of power relationships (Foucault, 1978, p. 93) and becomes a lever (Crocker et al., 2015; MacDonald et al., 2014; Redlich, Steadman, Robbins, \& Swanson, 2006), a "system of capture" for the mental health care system to take shape and operate in new and unfamiliar ways. Such process is experienced by some "as if [one] was in prison but outside" (Gibbs, 2010, p. 228). This metaphor illustrates the symbolic force of the judiciarization of mental illness as well as the disciplinary logic that can be inferred from it.

Different concerns are highlighted in the literature on the increased use of the justice systems to deal with PDMIs. First, is the risk of increased psychiatrization (or "pathologization") of social problems (AGIDD-SMQ, 2014; Comité Vigilance, 2011, Rogers \& Pilgrim, 2014), which is what sociologists Castel, Castel and Lovell (1979) defined as the "psychiatrization of difference". In the same vein, the primary emphasis on adherence to psychopharmacological treatment as the privileged form of intervention by psychiatric authorities is also heavily criticized (Comité Vigilance, 2011; Provencher, 2010; Watts \& Weinrath, 2017).

Second, double stigmatization in the context of justice system involvement is another problem that is frequently raised $(\mathrm{CAMH}$,
2013; Gouvernment du Québec, 2018; Marshal \& Adams, 2018). Such stigmatization can create fear among care providers of people who are judiciarized; that is, people who have come into contact with the law, have a judicial background and come to be reduced to such labels - a reality that is likely to complicate access to health care services (Frappier et al., 2009). On this subject, Marshall and Adams (2018) also indicate that this double stigma (mental illness and criminality) can have an impact on the quality of the therapeutic relationship between health care providers and judiciarized patients.

Added to this double stigma is the reality of systemic racism. There is evidence that racialized and Indigenous peoples are overrepresented in involuntary mental health services as well as in the criminal justice system in Canada (CAMH, 2013; Meerai, Abdillahi, \& Poole, 2016; Watts \& Weinrath, 2017). For instance, this form of discrimination particularly affects Black people, who are victims of a phenomenon defined by Meerai et al. (2016) as anti-Black sanism, i.e. "an oppression, a belief system, and the pervasive form of violence that makes it possible for psychiatric diagnosis, medication, and other 'therapeutics' to strip away dignity and livelihood" (p. 21). From a discursive standpoint, we can ask ourselves what "new" forms of governmentality are we dealing with if imprisonment has become the way marginalized and racialized populations are being managed? How can we understand judiciarization of PDMIs in a society that otherwise put so much emphasis on individual liberties, free markets, and the need to limit the power of "the state"? Evidently, the articles sourced for this paper fall short to help answer such questions but do set the stage for ongoing attention and problematization on the phenomenon of judiciarization. 


\section{The Instrumentalization of Care as a Strategy of Control}

The ways in which PDMIs are managed within the justice system are primarily carried out with a view to protecting the public (Peternelj-Taylor, 2008; Schneider, 2015). This emphasis on safety and public protection may, however, come in contradiction with the philosophies of care and recovery advocated in clinical settings and in the nursing discipline (e.g., autonomy, empowerment, self-determination and individualized care). As Gault (2009) states: "Mental health care is subject to continuous debate over the tension between caring for those with mental health problems and protecting the public." (p. 204) This dichotomy can create ethical and moral tensions for nurses working with patients involved in the justice system, as polarizing discourses of care and control (discipline) are at the forefront of many interventions (Mason, 2002).

As such, forensic-psychiatric nurses act from both a therapeutic and social control perspective (Jacob, 2012, 2014; Mason, 2002). In carrying out daily interventions, they equally engage in therapeutic acts as well as various mechanisms of "soft" coercion (forced medication, constant surveillance and mandatory home care visits, court appearance as expert witness, etc.). The involvement of nursing as a caring and therapeutic profession is what seems to legitimize and "soften" the coercive acts undertaken in such contexts. Inadvertently, there is a form of instrumentalization of nursing interventions that no longer serve only therapeutic ends, but are strongly affected by power dynamics inherent in the management (according to psychiatric expertise and discourses) of "deviant" and "at risk" populations (Foucault, 2003).

According to sociologist Jacques Donzelot (1979), we are now confronted with an expansion of the social field of psychiatry and justice, based on Deleuzian mechanisms of social control - ever increasing the grasp over individuals in complex networks of power relations (including health care). Several authors have argued that nurses who practise in forensic psychiatric contexts take part in coercive interventions as agents of social control, leading to significant role ambiguity (Gournay, 2005; Hörberg \& Dahlberg, 2015; Holmes, 2002; Jacob, 2012, 2014). This is a reality that is also present in general psychiatric settings, as well as in community care (Galon \& Wineman, 2010; Gault, 2009; Jager \& Perron, 2018). The preliminary results of a recent study conducted by the authors suggest that this instrumentalization of care comes to construct coercion, which very often results from the judiciarization of PDMIs, as a "necessary evil" (Andersson et al., 2020; Pariseau-Legault et al., 2019).

\section{Procedural Justice as an Extension of Pastoral Power}

In response to these dilemmas between the notions of care and control inherent to the psychiatric structures, some authors have recently raised the importance of introducing a procedural justice approach in both clinical and court settings: "the principles of procedural justice theory could be used to reconcile the tension between care and control" (Wittouk \& Beken, 2019, p. 19). This approach promotes what is considered a more open and constructive process that listens to the patient being judiciarized in order to reduce the perception of coercion experienced in judicial processes (Galon \& Wineman, 2010; Kopelovich et al., 2013). The implementation of this approachwhose central values are equity, voice, validation, transparency, inclusion and respect-would thus promote better involvement of patients in the therapeutic relationship in context of judiciarization 
(Wittouck \& Beken, 2019). As Maguire, Daffern and Martin (2014) argue, patients are more likely to accept coercion and mandatory treatment if they perceive that they are treated with respect and empathy. In forensic settings, the use of procedural justice has been presented as a way to enhance patient autonomy, while promoting more positive and harmonious relationships and interactions with care providers (Livingston, Crocker, Nicholls, \& Seto, 2016; Maguire et al., 2014). In keeping with our critique of the instrumentalization of care as an extension of social control, we wish to engage with the relatively uncritical approach with which the concept of procedural justice is being portrayed and adopted.

In the philosophical foundations of procedural justice, the court no longer has unique roles of punishment and sanction, but also a role of therapy and support (Canada \& Hiday, 2014; Kopelovich et al., 2013). These differing mandates required of the courtnow simultaneously called on to judge and treat-would appear to be in opposition. According to Castel et al. (1979), the appropriation of this therapeutic mandate by the judicial domain leads to "a confusion or a near-total lack of differentiation between justice and psychiatry" (p. 238). In effect, the establishment of specialized mental health courts has raised many questions for patients' rights organizations (Comité Vigilance, 2011; Provencher, 2010), and we would argue, contributes to the conditions that permits judiciarization to take place.

Among other things, we are witnessing the hybridization of roles and language. On the one hand, the courts are increasingly trying to embody clinical-read therapeuticprinciples and processes, and on the other hand, health professionals are increasingly adhering to and mastering legal jargon, a concept defined as "legalism" by Rogers and Pilgrim (2014). In addition, with procedural justice, nurses and mental health professionals now have a role in accompanying patients through the legal process - ensuring various forms of support for judiciarized persons, but also facilitating persuasion and supporting the overall process of legal proceedings. Once again, Foucault's work is particularly evocative with respect to expert discourses and the role mental health professionals are asked to play in the judicial system: "The sordid business of punishing is thus converted into the fine profession of curing. As well as serving other ends, expert psychiatric opinion serves to effect this conversion" (Foucault, 2003, p. 23).

According to our analysis, principles of procedural justice can be conceptualized as the introduction of pastoral forms of power in legal proceeding as they related to mental health cases. Pastoral power may be understood as a secular power (Tierney, 2004) that refers to practices of subjection (i.e., the government of self). This form of power is presented as follows by Wilson, Crowe, Scott and Lacey (2018): "exemplified historically in the Christian clergy, the notion of the 'pastoral' creates an image of the pastor who acts as shepherd in charge of a flock" (p. 355). In its practical form, pastoral power is implemented through the techniques of examination of conscience and confession (the Christian confessional principle), and can thus be considered as "the general operation of the examination, analysis, correction, and guidance of the penitent" (Foucault, 2003, p. 180). The exercise of this form of power allows the development of a relationship of subjection; it is therefore a power that invites acceptance and obedience on the part of the person being governed by someone who they trust.

Foucault informs us that this pastoral power is still in use in contemporary societies, particularly within the psychiatric-judicial apparatus (Foucault, 2003). With the exercise of such power (which can operate in parallel 
with disciplinary and sovereign forms of power), PDMIs come to accept the need for some form of coercion against them. The aim is therefore to make these people understand that this coercion, whether formal or informal, is applied for their own good and for the protection of the public.

From a neoliberal standpoint, we see the construction of a responsible subject, one that is rational, and acts in the interest of health and the safety of all (Esposito \& Perez, 2014). As Foucault would argue, the goal of such a process is the production of docility, for the patient to be "perfectly aware of his condition; [...] he demands the chains himself and, perhaps, his confinement." (Foucault, 2003, p. 144). In practice, it is nurses who exercise pastoral power in the context of their clinical functions (Holmes, 2002; Wilson et al., 2018). Through the therapeutic relationship they build with patients and within their new-found role in processes of procedural justice, they promote their patients' acceptance of coercion within the confines of psychiatric treatment and legal mechanisms (e.g., CTO, involuntary hospitalization, MHC, etc.). The individualizing force of such a role is not limited to passive observation or the application of technical procedures, as it is often suggested in the literature (Slemon, Jenkins, \& Bungay, 2017; Stevenson \& Cutcliffe, 2006). It is also part of an active and relational process. The people being cared for attribute legitimacy to nurses due to the benevolent nature of their professional practice and role in therapeutic interventions. In conceptualizing nursing work in the context of procedural justice enables us to make explicit operations of pastoral power as it not only opens up a form of confession that allows clinicians to access the subject's "truth", but also participate in the modification of his or her own conscience and conduct (Tierney, 2004).
In this respect, pastoral power makes it possible to reduce the perception of coercion and injustice among patients in judicial proceedings. Nevertheless, these clinical practices expected of mental health nurses and clinicians (e.g., active listening, explanation of the need to use the justice system, transparency, guidance and persuasion) remain rooted in a logic of social control and subjection that is carried out towards "difficult", "dangerous" and "abnormal" individuals (Foucault, 2003; Roberts, 2005; Rogers \& Pilgrim, 2014). Our analysis makes it possible to shed light on the dynamics of power (pastoral, disciplinary and sovereign), control and subjection that persist in clinical settings, and which are promulgated through apparently humanistic and neutral discourses (Foucault \& Chomsky, 2006). Consequently, there is a need to maintain a critical distance with respect to the very function of procedural justice.

\section{Recommendations Stemming From the Literature}

We have seen so far that justice system involvement of PDMIs is complex and can generate effects on both patients who may experience various forms of coercion, and nurses whose professional roles come to be blurred with processes of social control. Various recommendations are proposed in the literature to reduce or even prevent PDMIs' contact with the judicial system. One of the most cited recommendation is better access to mental health services in the community (Gouvernement du Québec, 2018; Lamb \& Weinberger, 2013), particularly in the context of forensic psychiatric services (Peternelj-Taylor, 2008). This includes the need for increased access to supportive housing where there is access to specialized mental health teams (CAMH, 2013; Lamb \& Weinberger, 2013). 
With regard to the justice system, it is recommended to avoid the criminalization of incivilities and minor offences where possible for people with mental disorders (Gouvernment du Québec, 2018). There is also a call for better support for PDMIs dealing with the justice system in order to avoid imprisonment and criminalizationsuch as proper legal representation (Gouvernment du Québec, 2018). Finally, it is recommended that in court and/or detention settings, PDMIs should be provided with access to specialized mental health care sooner (Kucirka \& Ramirez, 2019; Protecteur du citoyen, 2011).

However, these proposed recommendations stemming from the literature do not fix the complex power dynamics at play, or the discursive tensions between competing ethical, political and social imperatives inherent in the management of "risky" and "abnormal" populations (Foucault, 2003). On the one hand, promoting better access to mental health services in the community is likely to individualize the structural causes of vulnerability, such as racism and socioeconomic precariousness, and in some cases, contribute to the expansion of the psychiatric-judicial apparatus. On the other hand, the emphasis placed on specialized psychiatric care in order to avoid judiciarization is likely to legitimize the discourse of psychiatric "expertise", which, it should be remembered, contributes to the stigmatization and control of PDMIs. Indeed, several of these recommendations only reinforce existing power relations. Challenging structural inequities and being vigilant with regard to the discourse of psychiatric expertise, particularly with regard to the management of the "risks" posed by PDMIs, remain appropriate courses of action based on the principles of advocacy and social justice.

\section{Final Remarks}

In this article, we sought to provide a reflexive and theoretical perspective on the phenomenon of the judiciarization of PDMI. Our analysis was inspired by the work of French philosopher Michel Foucault and the results generated can be used to better understand the power relationships that exist in the context of nursing care within the psychiatric-judicial apparatus-namely exploring the construction of the judiciarized subject, problematizing the instrumentalization of nursing care, as well as the role nurses play in providing care and ensuring social control. By employing Foucault's work in our analysis, we come to conceptualize the psychiatric-judicial apparatus, as a disciplinary institution, as part of a society of control, within which nurses play integral functional and relational roles. Nurses who practise within this psychiatricjudicial apparatus must be conscious of their participation in such mechanisms, so as to engage with the professional tensions they create. If anything, the results of our analysis highlight the need to stimulate discussion and critical reflection among nurses and all health professionals concerning the judiciarization of PDMIs. We hope that this theoretical contribution will raise awareness of the existence of normative practices and discourses in health care settings and in nursing, too often taken for granted as good and well intentioned.

\section{Ethical permission}

No ethical approval was required for this article as it is a theoretical work that is not based on empirical research. 


\section{References}

Association des groupes d'intervention en défense des droits en santé mentale du Québec. (2014). L'autorisation judiciaire de soins: Le trou noir de la psychiatrie. Montréal, QC: Association des groupes d'intervention en défense des droits en santé mentale du Québec.

Allison, R., \& Flemming, K. (2019). Mental health patients' experiences of softer coercion and its effects on their interactions with practitioners: A qualitative evidence synthesis. Journal of Advanced Nursing, 75(11), 2274-2284. doi:10.1111/jan.14035

Andersson, U., Fathollahi, J., \& Gustin, L. W. (2020). Nurses' experiences of informal coercion on adult psychiatric wards. Nursing Ethics, 27(3), 741-753. doi:10.1177/0969733019884604

Arribas-Ayllon, M., \& Walkerdine, V. (2017). Foucauldian discourse analysis. In C. Willig \& W. Stainton Rogers (Eds.), The SAGE Handbook of Qualitative Research in Psychology (pp. 110-123). Los Angeles, CA: SAGE Publications.

Beaudoin, O., \& Robert, J.-M. (2012). Santé mentale et justice. Perspective des proches aidants: Un sentiment d'impuissance. Le Partenaire, 20(4), 21-28.

Bellot, C., Sylvestre, M. E. (2017). La judiciarisation de l'itinérance à Montréal : les dérives sécuritaires de la gestion pénale de la pauvreté. Revue générale de droit, 47, 11-44. doi:10.7202/1040516ar

Canada, K. E., \& Hiday, V. A. (2014). Procedural justice in mental health court: An investigation of the relation of perception of procedural justice to non-adherence and termination. The Journal of
Forensic Psychiatry \& Psychology, 25(3), 321-340. doi:10.1080/14789949.2014.915338

Castel, F., Castel, R., \& Lovell, A. (1979). The psychiatrization of difference. International Journal of Law and Psychiatry, 2(2), 235-247.

Centre for Addiction and Mental Health. (2013). Mental health and criminal justice policy framework. Retrieved from https://camh.ca//media/files/pdfs---public-policysubmissions/mh_criminal_justice_p olicy_framework-pdf.pdf

Cheek, J. (1999). Postmodern and poststructural approaches to nursing research. Thousand Oaks, CA: SAGE Publications.

Comité Vigilance. (2011). Judiciariser l'accès à des soins en santé mentale? Retrieved from http://www.cdcbecancour.ca/docum ents/2011-mai-memoire-a-proposdu-paj-sm.pdf.

Commissaire à la santé et au bien-être. (2012). Rapport d'appréciation de la performance du système de santé et de services sociaux 2012: Pour plus d'équité et de résultats en santé mentale au Québec. Retrieved from https://www.csbe.gouv.qc.ca/filead min/www/2012/SanteMentale/CSB E_Rapport_Appreciation_SanteMen tale_2012.pdf

Commission des droits de la personne et des droits de la jeunesse. (2009). The judiciarization of the homeless in Montréal: A case of social profiling. Retrieved from http://www.cdpdj.qc.ca/Publications /Homeless_Summary.pdf

Crocker, A. G., Nicholls, T. L., Seto, M. C., Charette, Y., Côté, G., \& Caulet, M. (2015). The National Trajectory Project of individuals found not criminally responsible on account of mental disorder in Canada. Part 2: 
The people behind the label. The Canadian Journal of Psychiatry, 60(3), 106-116.

Deleuze, G. (1992). Postscript on the societies of control. October, 59, $3-$ 7.

Dvoskin, J. A., Knoll, J. L., \& Silva, M. (2020). A brief history of the criminalization of mental illness. CNS Spectrums, 20, 1-13. doi:10.1017/S1092852920000103

Donzelot, J. (1979). The policing of families. New York, NY: Pantheon Books.

Elden, S. (2017). Foucault: The birth of power. London, UK: Polity.

Esposito, L., \& Perez, F. M. (2014). Neoliberalism and the commodification of mental health. Humanity \& Society, 38(4), 414442. doi:10.1177/0160597614544958

Foucault, M. (1978). The history of sexuality. New York, NY: Pantheon Books.

Foucault, M. (1980). Power/knowledge: Selected interviews and other writings, 1972-1977. New York, NY: Pantheon Books.

Foucault, M. (1991). Governmentality. In G. Burchell, C. Gordon, \& P. Miller (Eds.), The Foucault effect: Studies in governmentality (pp. 87-104). Chicago, IL: University of Chicago Press.

Foucault, M. (2003). Abnormal: Lectures at the Collège de France, 1974-1975. London, UK: Verso.

Foucault, M. (2009). History of madness. London, UK: Routledge.

Foucault, M., \& Chomsky, N. (2006). The Chomsky - Foucault debate: On human nature. New York, NY: The New Press.

Frappier, A., Vigneault, L., \& Paquet, S. (2009). À la fois malade et criminalisé: témoignage d'une double marginalisation. [Mentally ill and criminalized: testimony of a dual marginalization]. Santé mentale au Québec, 34(2), 21-30. doi:10.7202/039123ar

Galon, P. A., \& Wineman, N. M. (2010). Coercion and procedural justice in psychiatric care: State of the science and implications for nursing. Archives of Psychiatric Nursing, 24(5), 307-316. doi:10.1016/j.apnu.2009.12.005

Gault, I. (2009). Service-user and carer perspectives on compliance and compulsory treatment in community mental health services. Health \& Social Care in the Community, 17(5), 504-513. doi:10.1111/j.13652524.2009.00847.x

Gibbs, A. (2010). Coping with compulsion: Women's views of being on a community treatment order. Australian Social Work, 63(2), 223-233. doi:10.1080/03124070903265740

Gournay, K. (2005). The changing face of psychiatric nursing: Revisiting... Mental health nursing. Advances in Psychiatric Treatment, 11(1), 6-11. doi:10.1192/apt.11.1.6

Gouvernement du Québec (2018). Stratégie nationale de concertation en justice et en santé mentale: Agir ensemble pour une justice adaptée aux enjeux de santé mentale. Québec, QC: Ministère de la Justice.

Gray, J. E., Hastings, T. J., Love, S., \& O'Reilly, R. L. (2016). Clinically significant differences among Canadian mental health acts: 2016. The Canadian Journal of Psychiatry, 61(4), 222-226. doi:10.1177/0706743716632524

Holmes, D. (2002). Police and pastoral power: Governmentality and correctional forensic psychiatric nursing. Nursing Inquiry, 9(2), 84- 
92. doi:10.1046/j.1440-

1800.2002.00134.X

Hörberg, U., \& Dahlberg, K. (2015). Caring potentials in the shadows of power, correction, and discipline-Forensic psychiatric care in the light of the work of Michel Foucault. International Journal of Qualitative Studies on Health and Well-Being, 10(1), 28703. doi:10.3402/qhw.v10.28703

Jacob, J. D. (2012). The rhetoric of therapy in forensic psychiatric nursing. Journal of Forensic Nursing, 8(4), 178-187. doi:10.1111/j.19393938.2012.01146.x

Jacob, J. D. (2014). Understanding the domestic rupture in forensic psychiatric nursing practice. Journal of Correctional Health Care, 20(1), 45-58. doi:10.1177/1078345813505444

Jager, F., \& Perron, A. (2018). Caring as coercion: Exploring the nurse's role in mandated treatment. Journal of Forensic Nursing, 14(3), 148-153. doi:10.1097/JFN.000000000000020 7

Kearns, R. A. (1993). Place and health: Towards a reformed medical geography. The Professional Geographer, 45(2), 139-147. doi:10.1111/j.00330124.1993.00139.x

Kent-Wilkinson, A. E. (2010). Forensic psychiatric/mental health nursing: Responsive to social need. Issues in Mental Health Nursing, 31(6), 425431. doi:10.3109/01612840903506444

Kisely, S. R., Campbell, L. A., \& O'Reilly, R. (2017). Compulsory community and involuntary outpatient treatment for people with severe mental disorders. Cochrane Database of Systematic Reviews, 3, CD004408.
doi:10.1002/14651858.CD004408.p ub5

Kopelovich, S., Yanos, P., Pratt, C., \& Koerner, J. (2013). Procedural justice in mental health courts: Judicial practices, participant perceptions, and outcomes related to mental health recovery. International Journal of Law and Psychiatry, 36(2), 113-120. doi:10.1016/j.ijlp.2013.01.004

Kucirka, B. G., \& Ramirez, J. (2019). Challenges of treating mental health issues in correctional settings. Journal of Psychosocial Nursing \& Mental Health Services, 57(7), 711. doi:10.3928/0279369520190612-02

Lamb, H. R., \& Weinberger, L. E. (2013). Some perspectives on criminalization. Journal of the American Academy of Psychiatry and the Law, 41(2), 287293.

Lebenbaum, M., Chiu, M., Vigod, S., \& Kurdyak, P. (2018). Prevalence and predictors of involuntary psychiatric hospital admissions in Ontario, Canada: A population-based linked administrative database study.

BJPsych Open, 4(2), 31-38. doi:10.1192/bjo.2017.4

LeFrançois, B. (2014). Voluntary commitment. In A. Scull (Ed.), Cultural sociology of mental illness: An A-to-Z Guide (pp. 947-950). Los Angeles, CA: SAGE Publications.

Livingston, J. D., Crocker, A. G., Nicholls, T. L., \& Seto, M. C. (2016). Forensic mental health tribunals: A qualitative study of participants' experiences and views. Psychology, Public Policy, and Law, 22(2), 173184. doi:10.1037/law0000084

MacDonald, S.-A., Bellot, C., Sylvestre, M.È., Michaud, A.-A. \& Pelletier, A. (2014). Mental health courts: Processes, outcomes and impact on 
homelessness. Retrieved from https://www.homelesshub.ca/sites/d efault/files/attachments/HKDFinalR eport_2014.pdf

Maguire, T., Daffern, M., \& Martin, T. (2014). Exploring nurses' and patients' perspectives of limit setting in a forensic mental health setting. International Journal of Mental Health Nursing, 23(2), 153160. doi:10.1111/inm.12034

Marshall, L. A., \& Adams, E. A. (2018). Building from the ground up: Exploring forensic mental health staff's relationships with patients. The Journal of Forensic Psychiatry \& Psychology, 29(5), 744-761. doi:10.1080/14789949.2018.150848 6

Mason, T., \& Mercer, D. (1996). Forensic psychiatric nursing: Visions of social control. The Australian and New Zealand Journal of Mental Health Nursing, 5(4), 153-162.

Mason, T. (2002). Forensic psychiatric nursing: A literature review and thematic analysis of role tensions.

Journal of Psychiatric and Mental Health Nursing, 9(5), 511-520. doi:10.1046/j.13652850.2002.00521.x

Meerai, S., Abdillahi, I., \& Poole, J. (2016). An introduction to anti-black sanism. Intersectionalities: A Global Journal of Social Work Analysis, Research, Polity, and Practice, 5(3), 18-35.

Mental Health Commission of Canada. (2012). Changing directions, changing lives: The mental health strategy for Canada. Calgary, AB: Author.

Nyttingnes, O., Ruud, T., \& Rugkåsa, J. (2016). 'It's unbelievably humiliating'-Patients' expressions of negative effects of coercion in mental health care. International
Journal of Law and Psychiatry, 49, 147-153. doi:10.1016/j.ijlp.2016.08.009

O’Byrne, P., \& Jacob, J. D. (2019). The evolution of HIV prevention: From discipline to control. Advances in Nursing Science, 42(4), E1-E10. doi:10.1097/ANS.00000000000002 68

Office of the Ombudsperson. (2019). Commited to change: Protecting the rights of involuntary patients under the Mental Health Act (Special Report No. 42). Victoria, B.C. Retrieved from https://www.bcmhrb.ca/app/uploads /sites/431/2019/03/OMBCommitted-to-Change-FINALweb.pdf

O’Reilly, R. L., Keegan, D. L., Corring, D., Shrikhande, S., \& Natarajan, D. (2006). A qualitative analysis of the use of community treatment orders in Saskatchewan. International Journal of Law and Psychiatry, 29(6), 516-524. doi:10.1016/j.ijlp.2006.06.001

Paradis-Gagné, E., Holmes, D., \& Perron, A. (2020). Experiences of family violence committed by relatives with severe mental illness: A grounded theory. Journal of Forensic Nursing, 16(2), 108-117. doi:10.1097/JFN.000000000000027 2

Paradis-Gagné, E., \& Jacob, J. D. (2020). Judiciarization of people suffering from mental illness: A critical analysis of the psychiatric-judicial interface. Journal of Psychiatric and Mental Health Nursing. Advance online publication. doi:10.1111/jpm.12667

Paré, G., \& Kitsiou, S. (2017). Methods for literature reviews. In F. Lau \& C. Kuziemsky (Eds.), Handbook of eHealth evaluation: An evidence- 
based approach (pp. 157-179). Victoria, BC: University of Victoria. Pariseau-Legault, P., Vallée-Ouimet, S., Goulet, M.-H., \& Jacob, J. D. (2019). Nurses' perspectives on human rights when coercion is used in psychiatry: A systematic review protocol of qualitative evidence. Systematic Reviews, 8(1), 318. doi:10.1186/s13643-019-1224-0

Parker, I. (2013). Discourse analysis: Dimensions of critique in psychology. Qualitative Research in Psychology, 10(3), 223-239. doi:10.1080/14780887.2012.741509

Peternelj-Taylor, C. (2008). Criminalization of the mentally ill. Journal of Forensic Nursing, 4(4), 185-187. doi:10.1111/j.19393938.2008.00031.x

Poland, B., Lehoux, P., Holmes, D., \& Andrews, G. (2005). How place matters: Unpacking technology and power relations in health and social care. Health and Social Care in the Community, 13(2), 170-180. doi:10.1111/j.13652524.2005.00545.x

Prins, S. J. (2011). Does transinstitutionalization explain the overrepresentation of people with serious mental illnesses in the criminal justice system? Community Mental Health Journal, 47(6), 716722. doi:10.1007/s10597-011-9420$\mathrm{y}$

Protecteur du citoyen (2011). Rapport du protecteur du citoyen pour des services mieux adaptés aux personnes incarcérées qui éprouvent un problème de santé mentale. Retrieved from https://protecteurducitoyen.qc.ca/sit es/default/files/pdf/rapports_speciau $\mathrm{x} / 6-05-$

11_Rapport_sante_mentale_FINAL _fr_avec_lettre_au_president.pdf
Provencher, D. (2010). La judiciarisation des problèmes de santé mentale: Une réponse à la souffrance? $L e$ Partenaire, 19(1), 18-24.

Redlich, A. D., Steadman, H. J., Robbins, P. C., \& Swanson, J. W. (2006). Use of the criminal justice system to leverage mental health treatment: Effects on treatment adherence and satisfaction. Journal of the American Academy of Psychiatry and the Law, 34(3), 292-299.

Roberts, M. (2005). The production of the psychiatric subject: Power, knowledge and Michel Foucault. Nursing Philosophy, 6(1), 33-42. doi:10.1111/j.1466769X.2004.00196.x

Rogers, A., \& Pilgrim, D. (2014). A sociology of mental health and illness (5th ed.). Maidenhead, UK: Open University Press.

Schneider, R.D. (2015). The mentally ill: How they became enmeshed in the criminal justice system and how we might get them out. Department of Justice Canada.

Slemon, A., Jenkins, E., \& Bungay, V. (2017). Safety in psychiatric inpatient care: The impact of risk management culture on mental health nursing practice. Nursing Inquiry, 24(4), e12199. doi:10.1111/nin.12199

Stevenson, C., \& Cutcliffe, J. (2006). Problematizing special observation in psychiatry: Foucault, archaeology, genealogy, discourse and power/knowledge. Journal of Psychiatric and Mental Health Nursing, 13(6), 713-721. doi:10.1111/j.13652850.2006.01023.x

Tierney, T. F. (2004). Foucault on the case: The pastoral and juridical foundation of medical power. Journal of Medical Humanities, 
25(4), 271-290.

doi:10.1007/s10912-004-4833-z

Valenti, E., Banks, C., Calcedo-Barba, A.,

Bensimon, C. M., Hoffmann, K.-M.,

Pelto-Piri, V., ... Priebe, S. (2015).

Informal coercion in psychiatry: A

focus group study of attitudes and

experiences of mental health

professionals in ten countries. Social

Psychiatry and Psychiatric

Epidemiology, 50(8), 1297-1308.

doi:10.1007/s00127-015-1032-3

Watts, J., \& Weinrath, M. (2017). The

Winnipeg mental health court:

Preliminary findings on program

implementation and criminal justice

outcomes. Canadian Journal of

Community Mental Health, 36(1),

67-82. doi:10.7870/cjcmh-2017-005

Williams, J. (2005). Understanding poststructuralism. London, UK:

Acumen Pub.

Wilson, L., Crowe, M., Scott, A., \& Lacey, C. (2018). Psychoeducation for bipolar disorder: A discourse analysis. International Journal of Mental Health Nursing, 27(1), 349357. doi:10.1111/inm. 12328

Wittouck, C., \& Beken, T. V. (2019).

Recovery, desistance, and the role of procedural justice in working alliances with mentally ill offenders: A critical review. Addiction Research \& Theory, 27(1), 16-28. doi:10.1080/16066359.2018.151843 4 